\title{
Shallot Agribusiness Development Strategy in Purworejo Village, Malang District
}

\author{
Sri Hindarti ${ }^{1 *}$, Lia Rohmatul Maula ${ }^{1}$ \\ Agribusiness Department, University of Islam Malang, Indonesia
}

\begin{abstract}
The development of shallots is needed in Malang Regency to reduce imports, which often occur. Therefore this research was conducted with the aim of identifying internal and external factors that influence shallot agribusiness, formulating development strategies, and determining the priority of shallot agribusiness development strategies. The research was determined in Purworejo Village as one of the largest shallot production centers in Malang Regency. The research method was carried out by interview and direct observation of farmers. Data analysis using IFE analysis, EFE, IE (InternalExternal) matrix, SWOT matrix, and QSPM analysis. The results showed that the internal factors affecting shallot agribusiness were the skills and experiences of farmers as strengths and information and technology as weaknesses, while the external factors were market demand as an opportunity and distribution monopoly by large entrepreneurs as a threat. An appropriate strategy is an aggressive strategy (S-T), namely by utilizing strength to seize opportunities that exist in the form of local production input development.
\end{abstract}

Keywords: shallots, Malang Regency, strategy, SWOT

*Corresponding Author:

E-mail: srihin@unisma.ac.id (Sri Hindarti)

Agribusiness Department, University of Islam Malang, Indonesia

\section{INTRODUCTION}

According to Rahayu (1995), shallots are known to almost every country and region in the country. The plant, which is known internationally as shallot, is one of the high value commodities of horticulture and is needed by all levels of Indonesian society as a cooking ingredient. According to Wibowo (2008), onion is also known as a spice and medicinal plant because of its use as a spice and medicinal ingredients. Onion agribusiness is a source of income and job opportunities for farmers and contributes to regional economic development in Indonesia. According to BPS data (2018), the total national shallot production for the last five years was $1,233,989$ tons in $2014,1,229,189$ tons in $2015,1,446,869$ tons in $2016,1,470,155$ tons in 2017 and 1,503 .438 tons in 2018 . From this data it can be seen that shallot production has an upward trend of $2.26 \%$ in the 2017-2018 period. However, in 20142015 there was a decrease in production by $0.38 \%$ so that the price of shallots in that period jumped up to a price range of IDR 60,000 - IDR 80,000 per kilogram from the previous price of only IDR 12,000 - IDR 20,000 per kilogram. . Of course, this will affect the consumption pattern of society. In addition, the change in consumption patterns of the people will also spur demand for food products or similar raw materials to become increasingly diverse. This situation can lead to the development of certain consumer segments of specific demand for vegetable products, including the marketing prospects for shallot commodities (Sunarjono, 2001). The factors causing the decline in shallot production include unpredictable climatic conditions so that many farmers failed to harvest in various 
regions

(http://agritution.com/archives/458). In addition, several things need to be paid attention to in response to various issues and challenges in development such as conflicts over spatial use across sectors and regions, environmental quality degradation, development gaps between regions, and weak development coordination and control (Hariyanto \& Tukidi, 2007).

With the physical condition of shallots and seasonally dependent production characteristics, the supply of shallots fluctuates so that the selling price also fluctuates between seasons and between regions. Price fluctuations occur where during the harvest season the price of onions drops and vice versa when they are not harvested the prices jump very sharply. Likewise, the high cost of transportation causes a striking price difference in the price of shallots between producing areas and consumer areas. This is in contrast to the potential for agricultural land in Indonesia, which agroecologically allows for the fulfillment of domestic shallot needs. Not to mention that most farmers in production centers who use rice fields for shallot cultivation will still plant rice in certain seasons (Purba, 2014), although according to research by Aldila, Fariyant \& Tinaprilla (2015) onion agribusiness is far more profitable than rice agribusiness. Therefore, a strategy is needed in the development of shallots according to regional potential. According to Irawan (2007), to minimize fluctuations in the price of vegetables including onions, efforts are needed to develop vegetable production centers that are more spread out regionally. Ommani (2010) states that the identification of supporting and inhibiting factors originating from within and from outside is the first step in strategic planning for the development of an agricultural area.

Malang Regency is one of the largest shallot production districts in East Java, with the largest contributor to East Java being Nganjuk Regency with 38,051 tons, then Probolinggo Regency 6,046 tons, Malang Regency with 2,597 tons, and Kediri Regency with 1,162 tons (BPS, 2018). Shallots are a type of commercial crop produced in Malang Regency at this time. One of the shallot producing areas is Purworejo Village, Ngantang District, because the majority of the population cultivates shallots. Purworejo Village is considered quite potential in supplying the fulfillment of the need for shallots.

Onion production has not been able to keep up with the rapid population growth. Therefore, shallot production must be increased to meet the needs of the increasing population. The increase in shallot production is expected to increase farmers' income. Therefore, it is necessary to know the internal and external factors that influence shallot agribusiness and the appropriate strategies for its development.

\section{METHODS}

The research was conducted for 4 months starting from August to December 2019 on purpose (purposive) in Purworejo Village, Ngantang District, Malang Regency, as one of the production centers and the largest contributor of shallots in East Java. Collecting data obtained from interviews with questionnaires and direct observation of onion farmers in Purworejo Village on 40 farmers.

Analysis of the data was carried out through qualitative and quantitative descriptive analysis. Qualitative descriptive analysis is used to get about the opportunities, threats, strengths, and 
weaknesses of shallot agribusiness in Purworejo Village and the formulation of strategies using the SWOT matrix. Meanwhile, quantitative analysis uses the EFAS (External Factor Analysis Summary) matrix, IFE (Internal Factor Analysis Summary), IE (Internal-External) and QSPM (Quantitative Strategic Planning Matrix).

\section{RESULT AND DISCUSSION}

\subsection{Internal-External Factor Analysis}

\subsubsection{Identification of Internal Factors}

From observations and analysis results on shallot farmers in the research location, namely in Purworejo Village, Ngantang District, Malang Regency, the factors that can be identified as strengths and weaknesses in shallot agribusiness, namely:

a. Power

1. Farmers' skills and experience

2. Natural resource support

3. Availability of local inputs

4. Local government support

5. Renewable agricultural products

b. Weakness

1. Agricultural HR

2. Land and infrastructure conditions

3. Farmers' institutions

4. Capital

5. Information and technology

\subsubsection{Identification of External Factors}

External factors that become opportunities and threats in shallot agribusiness in the research location are as follows:

a. Opportunity

1. Market demand

2. Development of agro-industry

3. Cooperation with third parties

4. Research and technology

5. Farm credit / agricultural insurance

b. Threat

1. Production Risk

2. Price fluctuations for agricultural products

3. Imported products

4. Distribution monopoly by big businessmen

5. Climate Change

\subsection{IFE and EFE Matrix Analysis}

\subsubsection{IFE Matrix Analysis}

According to David (2009) the IFE (Internal Factors Evaluation) Matrix is a strategy formulation tool to summarize and evaluate the main strengths and weaknesses in the functional areas of the business and also provide a basis for identifying and evaluating the relationships between these functional areas. Based on the results of data analysis, the assessment of internal factors in shallot agribusiness in Purworejo Village, Ngantang District, Malang Regency, is summarized by the IFE (Internal Factors Evaluation) matrix as follows:

\begin{tabular}{|c|c|c|c|c|}
\hline \multirow{2}{*}{ No. } & \multirow{2}{*}{ Internal Factors Evaluation (IFE) } & \multicolumn{3}{|c|}{ Score $=$ Weight $\mathrm{x}$ Rating } \\
\hline & & Bobot & Rating & Score \\
\hline \multicolumn{5}{|c|}{ Strengths: } \\
\hline 1. & Farmers' skills and experience & 0,121 & 3,475 & 0,419 \\
\hline 2. & Natural resource support & 0,114 & 3,625 & 0,412 \\
\hline 3. & Availability of local inputs & 0,107 & 2,500 & 0,266 \\
\hline 4. & Local government support & 0,095 & 2,425 & 0,230 \\
\hline \multirow{2}{*}{ J. } & Renewable agricultural products & 0,102 & 2,050 & 0,210 \\
\hline & Total & 0,538 & 14,075 & 1,536 \\
\hline
\end{tabular}


Journal of Sustainable Develpment Science

Vol. 2, No. 2, December 2020, pp. 69-77

e-ISSN: 2715-9140 | p-ISSN: 2722-919X

\begin{tabular}{|l|l|c|c|c|}
\hline \multicolumn{2}{|l|}{ Weaknesses : } \\
\hline 1. & Farmers' institutional & 0,085 & 2,875 & 0,244 \\
\hline 2. & Agricultural Human Resources & 0,097 & 2,475 & 0,2401 \\
\hline 3. & Land and infrastructure conditions & 0,100 & 2,400 & 0,240 \\
\hline 4. & Capital & 0,091 & 2,525 & 0,229 \\
\hline 5. & Information and technology & 0,088 & 1,925 & 0,169 \\
\hline \multicolumn{2}{|c|}{ Total } & 0,461 & 12,200 & 1,1221 \\
\hline \multicolumn{2}{|c|}{ Total Internal Factors (S+W) } & 1,000 & 26,275 & 2,663 \\
\hline
\end{tabular}

Source: Primary Data Processed, 2020

The combination of these two internal factors resulted in a total IFE score for shallot agribusiness of 2.663 consisting of a strength score of 1.536 with the highest strength score of 0.419 , namely farmer skills and experience and a weakness score of 1.1221 with the lowest weakness factor score of 0.169 , namely information and technology. Purwanto (2005) said that experience can also shape attitudes as a process of increasing the knowledge possessed by farmers including the experience of using new technology. Therefore, by taking into account the existing strengths and weaknesses, shallot agribusiness still occupies a strategic position that is strong enough to continue to be developed because the strength factor is more dominant than the weakness factor.

\subsubsection{Analysis of the EFE Matrix}

According to David (2006), the External Factor Evaluation (EFE) matrix allows strategists to summarize and evaluate economic, social, cultural, demographic, environmental, political, government, legal, technological, and competitive information. External factors that become opportunities and threats from this shallot agribusiness are as follows:

\begin{tabular}{|c|c|c|c|c|}
\hline \multirow{2}{*}{ No. } & \multirow{2}{*}{ External Factors Evaluation (EFE) } & \multicolumn{3}{|c|}{ Score $=$ Weight $\mathrm{x}$ Rating } \\
\hline & & Weight & Rating & Score \\
\hline \multicolumn{5}{|c|}{ Oportunity: } \\
\hline 1. & Market Demand & 0,144 & 3,775 & 0,542 \\
\hline 2. & Agro-industrial development & 0,097 & 3,350 & 0,325 \\
\hline 3. & Farm credit / agricultural insurance & 0,096 & 2,100 & 0,201 \\
\hline 4. & Research and technology & 0,097 & 2,025 & 0,196 \\
\hline 5. & Cooperation with third parties & 0,069 & 1,875 & 0,129 \\
\hline \multicolumn{2}{|r|}{ Total } & 0,502 & 13,125 & 1,394 \\
\hline \multicolumn{5}{|c|}{ Threats : } \\
\hline 1. & Climate Change & 0,125 & 3,300 & 0,412 \\
\hline 2. & Shallot price fluctuation & 0,120 & 2,800 & 0,336 \\
\hline 3. & Production Risk & 0,108 & 2,250 & 0,243 \\
\hline 4. & Imported shallots & 0,080 & 1,525 & 0,122 \\
\hline 5. & Monopoly of distribution by large entrepreneurs & 0,065 & 1,200 & 0,078 \\
\hline \multicolumn{2}{|r|}{ Total } & 0,498 & 11,075 & 1,189 \\
\hline \multicolumn{2}{|r|}{ Total External Factors $(\mathrm{O}+\mathrm{T})$} & 1,000 & 24,200 & 2,584 \\
\hline
\end{tabular}

Source: Primary Data Processed, 2020

\section{Journal Homepage:}

http://ejournal.undwi.ac.id/index.php/jsds 
The combination of these two external factors resulted in a total EFE score for shallot agribusiness of 2.584 consisting of an opportunity score of 1.394 with the highest opportunity score of 0.542 , namely market demand and 1.189 threat score with the lowest threat factor score of 0.078 , namely monopoly distribution by large entrepreneurs. Taking into account the opportunities and threats that exist, shallot agribusiness is still in a strategic position to continue to be developed because the opportunity score is more dominant than the threat score.

\subsection{SWOT matrix}

The SWOT approach is a situation analysis tool that can help policy makers and stakeholders to formulate the initial steps of planning, controlling, and evaluating business processes based on resources and capabilities (Gürel \& Tat, 2017). To formulate the alternative strategies needed in developing shallot commodities in Purworejo Village, Ngantang District, using a SWOT matrix analysis. The SWOT matrix clearly illustrates how external opportunities and threats can be combined with internal strengths and weaknesses to produce a development strategy formulation for shallots. This matrix produces 4 possible cells, namely S-O strategy, S-T strategy, WO strategy, and W-T strategy.

After identifying internal and external factors which are the strengths and weaknesses as well as opportunities and threats in the development of shallot agribusiness in Pruworejo Village, Ngantang District, Malang Regency, using a SWOT matrix analysis, several alternative strategies are obtained as follows:

TABLE III

SWOT Analysis Matrix

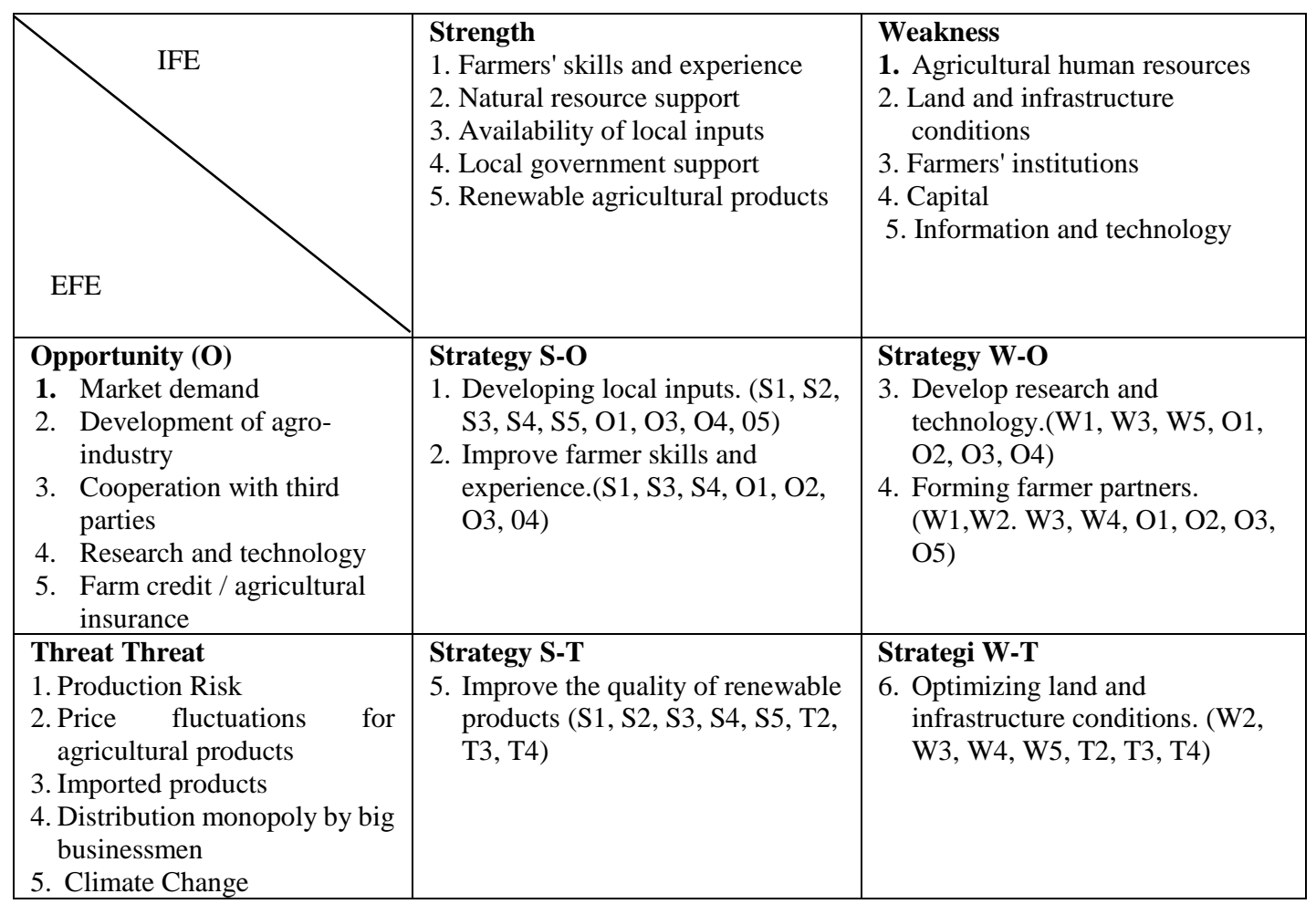

Source: Primary Data Processed, 2020

Journal Homepage:

http://ejournal.undwi.ac.id/index.php/jsds
Copyright $@ 2020$ Dwijendra University. All right reserved. 


\subsection{Internal-External Matrix}

Based on the IFE (Internal Factors Evaluation) and EFE (External Factors Evaluation) assessments carried out on the shallot agribusiness development strategy in Pruworejo Village, Ngantang District, Malang Regency. So, the total IFE average value is 2.663 with a strength score of 1.536 and a weakness score of 1.127 while the total EFE average value is 2.584 from the opportunity value of 1.394 and the threat value of 1.189

To find out the development in Purworejo Village, Ngantang District,
Malang Regency based on the assessment of internal and external factors, a reduction is made between the number of strengths and weaknesses on the (X) axis and a reduction between the number of opportunities and threats for the (Y) axis, then the value of $X=(\mathrm{SW})=1.536-1.127=$ 0.315 and the value of $\mathrm{Y}=(\mathrm{OT})=1.394$ $1.189=0.205$.

Thus, the numbers on the $\mathrm{X}$ and $\mathrm{Y}$ axes are 0.315 and 0.205 , respectively, which have positive values for the development of shallots in Purworejo Village, Ngantang District. For more details, it can be seen in Figure 1 .

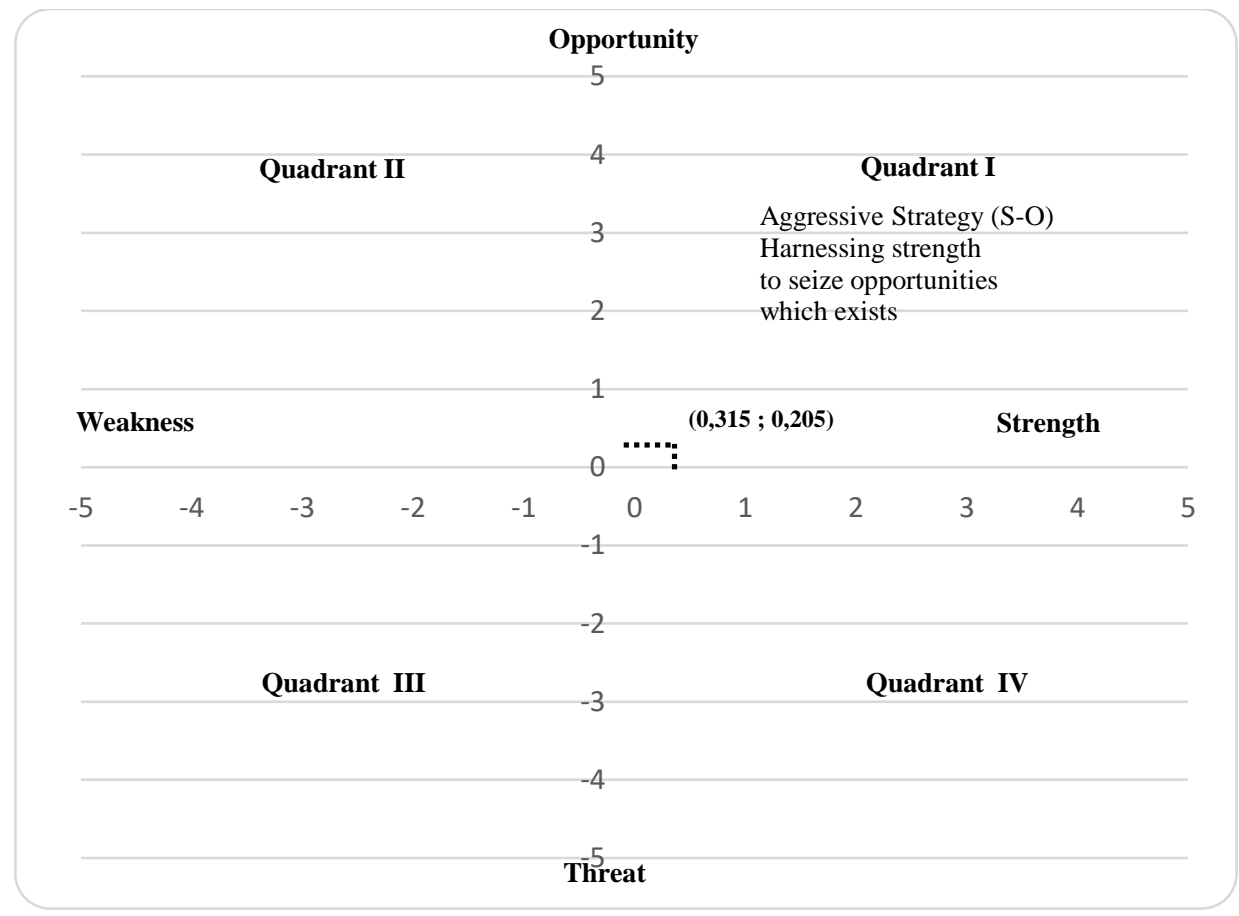

Fig. 1 Swot Matrix on Shallot Agribusiness Development

Based on Figure 1, it can be concluded that the shallot agribusiness is in quadrant I. Kiloes (2018) states that this position recommends an aggressive strategy by maximizing all the strengths that are owned to seize the available opportunities (SO). This strategy shows a very favorable situation. The development of shallots in Pruworejo Village, Ngantang District, can be done by using strength to take advantage of existing opportunities, such as utilizing the skills and experiences of farmers in meeting market demand for shallot commodities. Sumiati (2009) states that when a business has a major weakness, it will try to overcome it and make it a 
strength. Skills can be seen from the ability of farmers to carry out physical farming activities. Fadhilah et al (2018) stated that farmers who have good skills can make the right choice so they can find out what is efficient and effective (Rambe and Honorita, 2011).

\subsection{Quantitative Strategic Planning Matrix (QSPM)}

According to David (2006), the Quantitative Strategic Planning Matrix (QSPM) is an analytical technique designed to determine the relative attractiveness of viable alternative measures. Strategy alternatives based on SWOT analysis, namely internal and external factors. The results of the alternative selection are as follows:
1. Improve farmer skills and experience

2. Developing a local production input

3. Develop research and technology

4. Forming farmer partners

5. Improve the quality of renewable products

6. Optimizing land and infrastructure conditions

Based on the results of the QSPM analysis, it can be seen that the best strategy that can be done now is to improve product quality. This strategy is carried out as an effort to develop agribusiness as an effort to face the level of competition. Following are all the alternatives produced based on the formulation of the QSPM according to the ranking can be seen in table IV.

TABLE IV

Quantitative Strategic Planning Matrix of Shallot Agribusiness

\begin{tabular}{|c|l|c|c|l|}
\hline No. & \multicolumn{1}{|c|}{ Strategy } & Weight & AS & TAS \\
\hline 1. & Developing a local production input & 0,945 & 4 & 3,780 \\
\hline 2. & Improve farmer skills and experience & 0,757 & 4 & 3,028 \\
\hline 3. & Forming farmer partners & 0,779 & 3 & 2,337 \\
\hline 4. & Develop research and technology & 0,671 & 3 & 2,313 \\
\hline 5. & Improve the quality of renewable products & 0,847 & 3 & 2,541 \\
\hline 6. & Optimizing land and infrastructure conditions & 0,684 & 2 & 1,368 \\
\hline
\end{tabular}

Source: Primary Data Processed, 2020

The QSPM matrix in table IV can determine the main priority strategies of the alternative strategies for the development of shallot agribusiness. QSPM mastrix calculation is done by multiplying the average weight of each factor of the internal and external environment with the value of attractiveness (Attractiveness Score-AS), in order to obtain the total value of attractiveness (Total Attractiveness ScoreAS). The alternative strategy with the

\section{Journal Homepage:}

http://ejournal.undwi.ac.id/index.php/jsds largest total value is the best strategy. (David, 2002).

Based on the results of the QSPM analysis, it can be seen that the priority of alternative strategies from the existing strategy alternatives is to develop local inputs as the first ranked strategy with a total weight of 3,780. Aldila, Fariyanti \& Tinaprilla (2017) stated that the development of local seedlings is an important thing to increase the supply of quality shallot seeds.of 3,780. Aldila, 
Fariyanti \& Tinaprilla (2017) stated that the development of local seedlings is an important thing to increase the supply of quality shallot seeds.

\section{CONCLUSIONS}

\section{Conclusion}

The results showed that 1) internal factors that affect shallot agribusiness are the skills and experiences of farmers with a score of 0.419 as strength and information and technology with the lowest score of 0.169 as weaknesses, while external factors are market demand with a score of 0.542 and distribution monopoly by large entrepreneurs with 0.078 as a threat, 2) The appropriate strategy is an aggressive strategy, namely by utilizing the power to seize existing opportunities, 3) the alternative priority of shallot agribusiness development strategies is to develop local inputs as the first order strategy in the QSPM analysis with a total weight of 3,780. It is hoped that this can be a consideration for the government and farmers in the development of shallot agribusiness in Purworejo Village, Ngantang District, as an area that has quite good potential in shallot agribusiness in Malang Regency.

\section{Suggestions}

From the results of this study, it is hoped that it can become a consideration for the government and farmers in the development of shallot farming in Purworejo Village, Ngantang District, as an area that has good potential in shallot farming in Malang Regency as a form of reducing the level of fluctuation in shallot commodities.

\section{REFERENCE}

Aldila, HF. Fariyanti, A. and Tinaprilla, N. (2015). Analysis of the profitability of shallot farming by season in three production center districts. SEPA Journal, Vol. 11, No. 2, 249-260.

Aldila, HF, Fariyanti, A \& Tinaprilla, N. (2017). Competitiveness of shallots in production centers in Indonesia. Journal of Management and Agribusiness, Vol. 14, No. 1, PP. 4353.

Anonymous. (2017). The factors causing the decrease in shallot production. http://agritution .com/archives/458 Accessed January 13, 2020.

Central Statistics Agency. (2018). East Java Province in Figures 2016. https://jatim.bps.go.id /publication/2016/07 Accessed January 14, 2020.

David, Fred R. (2002). Strategic Management, Jakarta: Salemba Empat.

David, Fred R. (2006). Strategic Management, Issue Ten. Jakarta: Four Salemba.

David, Fred R. (2009). Strategic Management. Jakarta: Four Salemba

Fadhilah, M. L., B. T. Eddy and S. Gayatri. (2018). The Influence of the Level of Knowledge, Attitudes and Skills of the Application of Agribusiness Systems on Production of Rice Farmers in Cimanggu District, Regency. Journal of Agricultural Socio-Economics 2 (1): $39-4$

Gürel, E \& Tat, M. (2017). 'Swot Analysis: a theoretical review', The Journal of International Social Research, vol. 10, no. 51, pp. 6-11.

Kiloes, A. M., Hardiyanto, Anna Sulistyaningrum, and M. Jawal Anwarudin Syah. (2018). Onion Agribusiness Development Strategy in Solok Regency (Shallot Agribusiness Development Strategy in Solok Regency). Horticulture Research and Development Center. Journal of Horticulture Vol. 28 No. 2

Hariyanto \& Tukidi. (2007). The concept of regional development and spatial planning in Indonesia in the era of regional autonomy. Journal of Geography, vol. 4, no. 1, pp. 1-10.

\section{Journal Homepage:}

http://ejournal.undwi.ac.id/index.php/jsds
Copyright $\odot 2020$ Dwijendra University. All right reserved. 
Journal of Sustainable Develpment Science

Vol. 2, No. 2, December 2020, pp. 69-77

e-ISSN: 2715-9140 | p-ISSN: 2722-919X

Irawan, B. (2016). Price fluctuation, price transmission, and vegetable and fruit marketing margins. Agricultural Policy Analysis, 5 (4), 358-373.

Ommani, AR. (2010). Strengths, weaknesses, opportunities and threats (SWOT) analysis for farming system businesses management: Case of wheat farmers of Shadervan District, Shoushtar Township, Iran ', African Journal of Business Management, vol. 5, no. 22, pp. $9448-9454$

Purba, R. (2014). Production and profit of four onion varieties out of season (offseason) in Serang Regency, Banten. Agriekonomika, Vol. 3, No. 4, 55-64.

Purwanto. (2005). Educational goals and learning outcomes. Ministry of Education's Technodic Journal. Jakarta.
Rahayu, 1995. Shallots. Self-help spreader, Jakarta.

Rambe, S. S. M., and B. Honorita. (2011). The behavior of farmers in farming in lowland swamps. Proceedings of the National Seminar on Agricultural Cultivation 2 (1): 115-128

Sumiati, Uum. (2009). Business Development Strategy for Fried Shallots PO Mekar Wangi, Taraju Village, Sindang Agung District, Kuningan Regency. Essay. Department of Agribusiness, Bogor Agricultural University.

Sunarjono, Hendro. (2001). Shallot Cultivation, Bandung: Sinar Baru Algensindo

Wibowo, Singgih. (2008). Cultivation of Shallots, Garlic and Onions. Jakarta: Penebar Swadaya

\section{Journal Homepage:}

http://ejournal.undwi.ac.id/index.php/jsds
Copyright (C) 2020 Dwijendra University. All right reserved. 